\title{
Studies on some phytoplankton and phytobenthos from Lake Qaroun, El-Fayoum Egypt
}

\author{
Entesar A. Ahmed \\ Botany and Microbiology Department, Faculty of Science, Al-Azhar University \\ (Girls Branch), Cairo, Egypt.
}

\begin{abstract}
:
The present investigation concerned with the study of the algal flora from four different regions of Qaroun Lake. Phytoplankton and Phyto-benthos materials were collected during August 2019. Physical and chemical characters of water at the investigated region of the lake were studied, a total of 23 microalgal species were identified related to Cyanophyta with 10 species, 8 species to Chlorophyta, 4 species for Bacillariophyta and Euglenophyta with one species. The physico-chemical characteristics of water and soils in relation to algal distribution have also been considered. Analyze the possibility of growing microalgae Scenedesmus quadricauda in wastewater as a potential candidate for biodiesel production. Fatty acid composition and the effect of sewage water on ultrastructure of Scenedesmus quadricauda by using the Transmission Electron Microscope were investigated revealed drastic changes in the overall ultrastructure such as the chloroplast separated far from the wall, accumulation of starch and the pyrenoid disappeared. These responses of Scenedesmus quadricauda indicated their tolerance of waste water
\end{abstract}

Keywords: Microalgae; physico-chemical; Scenedesmus quadricauda; Lake Qaroun.

\section{Introduction}

The lake's main sources of water are from agriculture drainage and domestic wastewater. Qaroun Lake is an inland closed basin, located in the deepest part of Fayoum depression (Meshal, 1977) originated from the old lake Moreis (freshwater Lake). It is located in the western desert in El-Fayoum depression, $90 \mathrm{Km}$ southwest of Cairo. Qaroun Lake is considered the oldest natural lakes in the world, the third largest lake in Egypt.

Qaroun Lake is one of the most important inland aquatic ecosystems in Egypt. The lake receives the agricultural drainage water from the surrounding cultivated land. Most of the drainage water reaches the lake by two main drains, 
El-Bats drain (at the northeast corner $50.9 \mathrm{Km}$ long), and El-Wadi drain (near mid-point of the southern shore $48.5 \mathrm{Km}$ long) (Abdel-Satar et al., 2010).

Salinity of Lake Qaroun increased throughout the $20^{\text {th }}$ century, being around 11\% in the early 1900s (Ball, 1939). In the 1980s, mean salinity reached to $\sim 38 \%$ but, since then, has stabilized. Since the lake is located in arid area, soluble salts increase during summer principally due to evaporation $\left(\sim 7 \mathrm{mmh}^{-1}\right.$, data supplied by the Irrigation Department, El-Fayoum), and low precipitation. According to Fathi and Flower (2005) the salinity of the lake is not homogenous, being lower near the discharging points of the two drains. The lake Qaroun receives agricultural waste water from cultivated lands (Abdel-Satar $\boldsymbol{e t}$ al., 2003). The high evaporation rate of water $\left(16.78 \mathrm{~cm} \mathrm{month}^{-1}\right)$, gradual increase of its salinity, trace metals and pollution affect greatly its water quality and its food potential, web including living organisms. Therefore, physicochemical affect deeply on super eutrophic Lake Qaroun (Abdel-Monem and Konswa, 2001).

Increasing of salinity is usually causes changing in composition and biomass of phytoplankton, noting the complete disappearance of some species nevertheless, some others were able to withstand the high salinity. Some studies were with phytoplankton composition and biomass in Lake Qaroun; El-Awamri (1984) identified 173 benthic diatoms taxa near the estuaries drains, 156 taxa away from the estuaries drains and 47 phytoplankton taxa in the water of Lake Qaroun. Also,Abdel Moniem (1991) identified 119 taxa where he recorded that the phytoplankton community inhabiting the Lake is mainly formed of Bacillariophyceae (64\%) followed by Dinoflagellates (27\%) whereas Kobbia $\boldsymbol{e t}$ al. (1992) recorded 64 taxa and another investigation by Abdel-Moniem (2001) recorded 50 taxa.

Interaction of both the physical parameters such as temperature, turbidity and chemical properties of water plays a significant role in the composition, distribution and abundance of aquatic ecosystem. Apart from this, it also gives an insight into the relationships between the organism and their environment and can be used in determining water quality, and productivity of the lake. The physico-chemical study could also help in understanding the structure and function of a particular water body in relation to its habitants Hutchison (1957). 
The increasing pollution of water resources in Lake Qaroun and the consequent harmful effects on aquatic environment and human health is an issue of great concern. However, waste waters contained a high amount of organic and inorganic nutrients which are suitable for growth of microalgae Gani $\boldsymbol{e t}$ al. (2016). Singh et al. (2021) reported that microalgae can play a pivotal role in degrading the complex pesticides and a part from toxic pollutant removal, microalgae produce biomass, thereby acts as the efficient source of additional products like biofuel, carbohydrates, lipids and proteins which can make phycoremediation more frugal and sustainable. Lipids are considered the most valuable components of microalgal biomass for the production of biodiesel. Scenedesmaceae family is one of the most popular food sources in experiments with herbivorous zooplankton (Lürling $\boldsymbol{e t}$ al., 1997), and also a potential source of lipids that constitute up to $47 \%$ dry weight (DW) (Ferrigo et al., 2015), particularly PUFAs group, including oleic, linoleic and alphalinolenic acids (Goswami and Kalita, 2011).

The cultivation of microalgae on wastewater to obtain biodiesel can be an economically feasible strategy with minimal environmental impacts. In consideration of all these facts, this study focuses on studying the evaluation of physical and chemical characteristics of Lake Qaroun water. Therefore, the present study has been undertaken to study the phytoplankton and phtobenthos from four stations of Lake Qaroun (El-Batts drain-before save belt and after the save belt and compared with in front of the save and in front of Oberg). As well as on the effect of waste water on the isolated Scenedesmus quadricauda biomass, lipid production and fatty acids composition as potential biodiesel producers.

\section{Materials and Methods}

\section{Study area}

Lake Qaroun is situated between longitudes of $30^{\circ} 24^{\prime}$ and $30^{\circ} 49^{\prime} \mathrm{E}$ and latitudes $29^{\circ} 24^{\prime}$ and $29^{\circ} 33^{\prime} \mathrm{N}$. In the present study, four stations were selected; El-Bats Drain-before save belt, after the save belt, in front of the save belt and in front of El-Oberg at El-Fayoum governorate (Table 1). 
Table 1: Collection samples in four stations at Lake Qaroun.

\begin{tabular}{lccc}
\hline & Stations & Longitude & Latitude \\
\hline 1 & El-Bats drain-before save belt & $30^{\circ} 50^{\prime} 36.76^{\prime \prime}$ & $29^{\circ} 30^{\prime} 13.89^{\prime \prime}$ \\
2 & After the save belt & $30^{\circ} 48^{\prime} 21.43^{\prime \prime}$ & $29^{\circ} 30^{\prime} 27.58^{\prime \prime}$ \\
3 & In front of the save belt & $30^{\circ} 48^{\prime} 20.93^{\prime \prime}$ & $29^{\circ} 29^{\prime} 8.95^{\prime \prime}$ \\
4 & In front of El-Oberg & $30^{\circ} 46^{\prime} 12.05^{\prime \prime}$ & $29^{\circ} 28^{\prime} 29.77^{\prime \prime}$ \\
\hline
\end{tabular}

\section{Sample Collection and analyses:}

Water and wet soil samples were collected during August 2019 from four stations of Lake Qaroun (Figure 1). A water samples were used to collect surface water (at $0-15 \mathrm{~cm}$ depth) in sterilized bottles from the different stands and kept in well stopper polyethylene plastic bottles for most chemical analyses. The soil collection was carried out according to John (1942). The surface soil layers, normally from a depth of $2.0 \mathrm{~cm}$ were removed with a knife and were freed from gravels and debris and collected in sterile plastic bags. Each water and soil sample represents a mixture of four random samples from each station. The collected samples were kept in an ice box and transported to the laboratory (Desert Research Center) for analysis of different chemical and physical characteristics of soil and water as well as the culturing, isolation, identification and then purification of algae.

\section{Physicochemical Analysis:}

Water analysis:

Water $\mathrm{pH}$ was measured by a glass electrode $\mathrm{pH}$ meter 3510 , Jenway, UK. and the electric conductivity (E.C.) was estimated by electric conductivity meter (Orion 150A+, Thermo Electron Corporation, USA).

\section{Soil analysis:}

Soil-water extracts of 1:2.5 were prepared and used for analyzed with respect to their EC (Electrical Conductivity) determine by (EC meter Orion 
150A+, Thermo Electron Corporation, USA), and $\mathrm{pH}$ by (pH meter, 3510, Jenway, UK). A total dissolved solid (TDS) was determined by filtering a volume of sample through a glass fiber filter $(\mathrm{GF} / \mathrm{C})$, and a known volume of filtrate was evaporated at $105^{\circ} \mathrm{C}$. The water and soil samples were subjected to the following chemical analyses: carbonate and bicarbonate estimation by (Jackson, 1962), Chloride by (Vogel, 1961). Flame photometric technique (PFP 7, Jenway, UK.) was used for $\mathrm{Na}$ and $\mathrm{K}$ determination in the investigated soil samples using $\mathrm{Na}$ and $\mathrm{K}$ standard solutions.

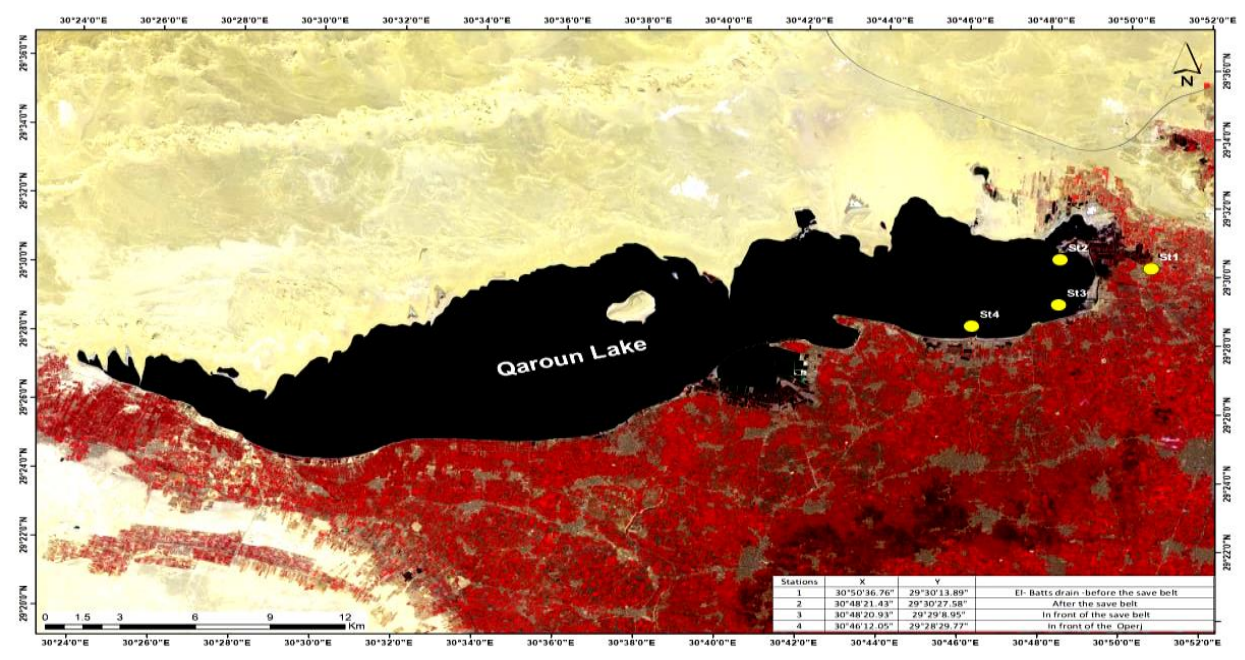

Figure 1: Map of Qaroun Lake showing the selected studied area

\section{Culturing, isolation and identification of algal taxa:}

Culturing studies are essential for isolation, and correct identification of algae (Round, 1984). Samples were grown in Z-medium (Staub, 1961), and BG11 according to (Browitzka and Browitzka, 1988) liquid and solid media. After colonization, the algal species were transferred to the same medium. Each isolated algal species was cultured in a $250 \mathrm{ml}$ flask containing $100 \mathrm{ml}$ of $\mathrm{Z}$-medium and BG11 medium without shaking, for 30 days. The incubation temperature was $28^{\circ} \mathrm{C} \pm 2$ and light intensity of 3000 lux with a white continuous light and a 
photoperiod regime of $16 \mathrm{hrs}$ light $8 \mathrm{hrs}$ dark. The isolated algae were identified using morphological variation studies and taxonomical approaches according to (Prescott, 1962).

\section{Culture Conditions}

Scenedesmus quadricauda was cultivated in sterilized 1-liter conical flasks containing $600 \mathrm{ml}$ of the corresponding culture medium (control culture medium BG11 and wastewater El-Bats drain) under previous continuous illumination.

\section{Total Lipid Extraction}

Total lipids were extracted from fresh microalgal biomass using the simplified Folch method (Folch et al., 1957). The lipids were extracted using a mixture of chloroform/methanol $(2: 1 \mathrm{v} / \mathrm{v})$ and $0.73 \% \mathrm{NaCl}$ water solution. The quantity of total lipids was measured gravimetrically and expressed as dry weight percentage. Total lipid extraction was performed in five replicates. The weight of the crude lipid obtained from each sample was measured.

\section{Fatty Acid and Gas chromatography-mass spectrometry (GC-MS) analysis}

The fatty acid profile of the extracted oil sample from algal species was determined by converting the fatty acids in the oil to fatty acid methyl esters (FAMEs). The FAME composition was determined using Gas-Chromatography (GC) with a split automatic injector and silica capillary column DB-5 (length: 60 m; ID: $0.32 \mathrm{~mm}$.). Analysis was determined at the Regional Center for Mycology and Biotechnology (RCMB) at Al- Azhar University.

\section{Transmission Electron microscopy}

The preparation of algal cell for transmission electron microscope was carried out according to the method of (Palade $\boldsymbol{e t}$ al., 1952) and the sections were then observed with a JEOL - JEM 1010 transmission electron microscope at 70 $\mathrm{kV}$ at The Regional Center for Mycology and Biotechnology (RCMB), Al- Azhar University. 


\section{Results and Discussion}

\section{Physico-chemical characteristics of lake:}

Physico-chemical analyses of water and soil samples from four stations in Lake Qaroun (Table 2), indicated that the water and soil extract were alkaline in all samples and the maximum value was recorded in the station 1 (9.6 and 8.7) for water and soil extract respectively followed by the station 4 which recorded (9.1 and 8.4) for water and soil extract respectively.

The highest $\mathrm{pH}$ value was recorded during summer, this might be attributed to high photosynthetic due to the abundance of the algal population and increase of carbonate Reid (1961). Simultaneously, high electric conductivity (EC) reached a maximum value of $42200 \mu \mathrm{S} / \mathrm{cm}$ at station 4 for water sample and a minimum value of $4890 \mu \mathrm{S} / \mathrm{cm}$ was recorded at station 1 for water sample. On the other hand, soil extract recorded high value of $14.45 \mu \mathrm{S} / \mathrm{cm}$ at station 3 compared to station 1 which record lowest value of $1.446 \mu \mathrm{S} / \mathrm{cm}$. This is in agreement with that reported by (Afify et al., 2019). The increase in EC values of lake Qaroun during summer may be attributed to the decrease in the water level as a result of high evaporation rate and lowering the amount of drainage water poured into the Lake. $\mathrm{pH}$ values were found in the permissible limits and ranged between 7.29 - 8.84.

Also, Table (2) showed high TDS values for all four stations water samples and soil extract, the highest values ranged between $24926 \mathrm{mg} / \mathrm{l}$ at site 4 and lowest value $3021 \mathrm{mg} / \mathrm{l}$ at sit 1 . These variations may be due to the size of the water body, inflow of water, consumption of salt by algae and other aquatic plants, and the rate of evaporation Lashari et al. (2009). The increasing in TDS values due to collected samples during summer season, may be attributed to the high evaporation rate. These results were agreed with that reported by Authman and Abbas (2007). 
Table 2. The physical and chemical parameters at studied stations.

\begin{tabular}{|c|c|c|c|c|c|c|c|c|}
\hline \multirow{3}{*}{ Parameter } & \multicolumn{8}{|c|}{ Stations } \\
\hline & \multicolumn{2}{|c|}{1} & \multicolumn{2}{|c|}{2} & \multicolumn{2}{|c|}{3} & \multicolumn{2}{|c|}{4} \\
\hline & water & soil & water & soil & water & soil & water & soil \\
\hline pH & 9.6 & 8.7 & 8.9 & 8.2 & 8.8 & 8.4 & 9.1 & 8.4 \\
\hline $\begin{array}{c}\text { Electrical } \\
\text { conductivity } \\
(\mathrm{EC}) \mu \mathrm{S} / \mathrm{cm} \\
\end{array}$ & 4890 & 1.446 & 20280 & 13.72 & 34400 & 14.45 & 42200 & 4.52 \\
\hline $\begin{array}{c}\text { Total dissolved } \\
\text { solids (TDS) } \\
\text { mg/l } \\
\end{array}$ & 3021 & 919 & 13626 & 8093 & 22413 & 8901 & 24926 & 2961 \\
\hline Calcium(mg/l) & 116.48 & 2.491 & 644.80 & 20.758 & 416.00 & 29.062 & 790.40 & 5.397 \\
\hline $\begin{array}{c}\text { Magnesium } \\
(\mathrm{mg} / \mathrm{l})\end{array}$ & 80.87 & 2.078 & 126.36 & 24.940 & 758.16 & 16.627 & 1794 & 3.325 \\
\hline Sodium (mg/l) & 800 & 9.131 & 3800 & 89.13 & 6400 & 97.83 & 5400 & 34.78 \\
\hline $\begin{array}{c}\text { Potassium } \\
(\mathrm{mg} / \mathrm{l})\end{array}$ & 25 & 0.740 & 90 & 2.168 & 150 & 2.652 & 175 & 0.638 \\
\hline $\begin{array}{c}\text { Carbonate } \\
(\mathrm{mg} / \mathrm{l})\end{array}$ & 30.0 & Nil & 30.0 & Nil & 36.0 & Nil & 30.0 & Nil \\
\hline $\begin{array}{c}\text { Bicarbonate } \\
(\mathrm{mg} / \mathrm{l})\end{array}$ & 12.2 & 1.30 & 18.3 & 1.80 & 36.6 & 1.50 & 61.0 & 1.70 \\
\hline $\begin{array}{c}\text { Sulphate } \\
(\mathrm{mg} / \mathrm{l})\end{array}$ & 1106 & 7.7 & 5206 & 30.5 & 4847 & 41.5 & 6136 & 30.1 \\
\hline $\begin{array}{c}\text { Chloride } \\
\text { (mg/l) }\end{array}$ & 856 & 5.520 & 3719 & 104.88 & 9787 & 104.88 & 10570 & 13.80 \\
\hline
\end{tabular}

Furthermore, chemical analysis indicated that, the studied water and soil had calcium-sodium, magnesium and potassium cationic and, bicarbonate, sulphate and chloride anionic structures recorded lowest value at station 1 and 
highest value at station 4. Carbonate not detected in soil extract at four stations, with constant value of water sample $(30.0 \mathrm{mg} / \mathrm{l})$ except station 3 which recorded high value $(36.0 \mathrm{mg} / \mathrm{l})$. The increase in salinity has been attributed mainly to the evaporative concentration of drainage water within the lake (Rasmy and Estefan, 1983). One of the reasons, for increasing salinity is the increase in the total dissolved solids, of the drain water over many years (Abdel Wahed et al. 2015).

Algal growth was recorded after three weeks from the start of incubation period. Total 23 algal taxa were isolated and identified from soil and water sample (Table 3).

Algal assessment and monitoring of lakes water are illustrated in (Table 3). Distribution of algae depends largely upon many factors that might affect the existence of algae in lake temperature, salinity, light intensity and grain size composition, directly affecting many species by limiting vertical distribution and burrowing performance (Asmus, 1982). Generally, as shown from the obtained results the maximum number of species was recorded in site 1(El-Bats drainbefore save belt).

According to the present results, it seems that Qaroun lake and its outlet were generally dominated by Cyanophyta 10 species Table (3) This observation could be interpreted as due to the slightly alkaline values of the water and soils, which favor the growth of blue-green algae (Singh et al., 1990 and Nair et al., 1993).

Chlorophyta recorded 8 species, Bacillariophyta recorded 4 species while Euglenophyceae recorded one species. These results agree with AbdelHameed et al. (2007) who illustrated that Cyanophyta dominated during summer season with 11 species isolated from Wadi El-Rayan, Also, Kobbia (1982) pointed out that green phytoplankton dominated during summer accompanied by blue-green organisms, while diatoms flourished during autumn and winter. The present study showed that the highly numerous Chlorophyta members from site 1 (El-Bats drain before save belt) compared to other sites and dominant by family Scenedesmaceae which appeared in this site only. 


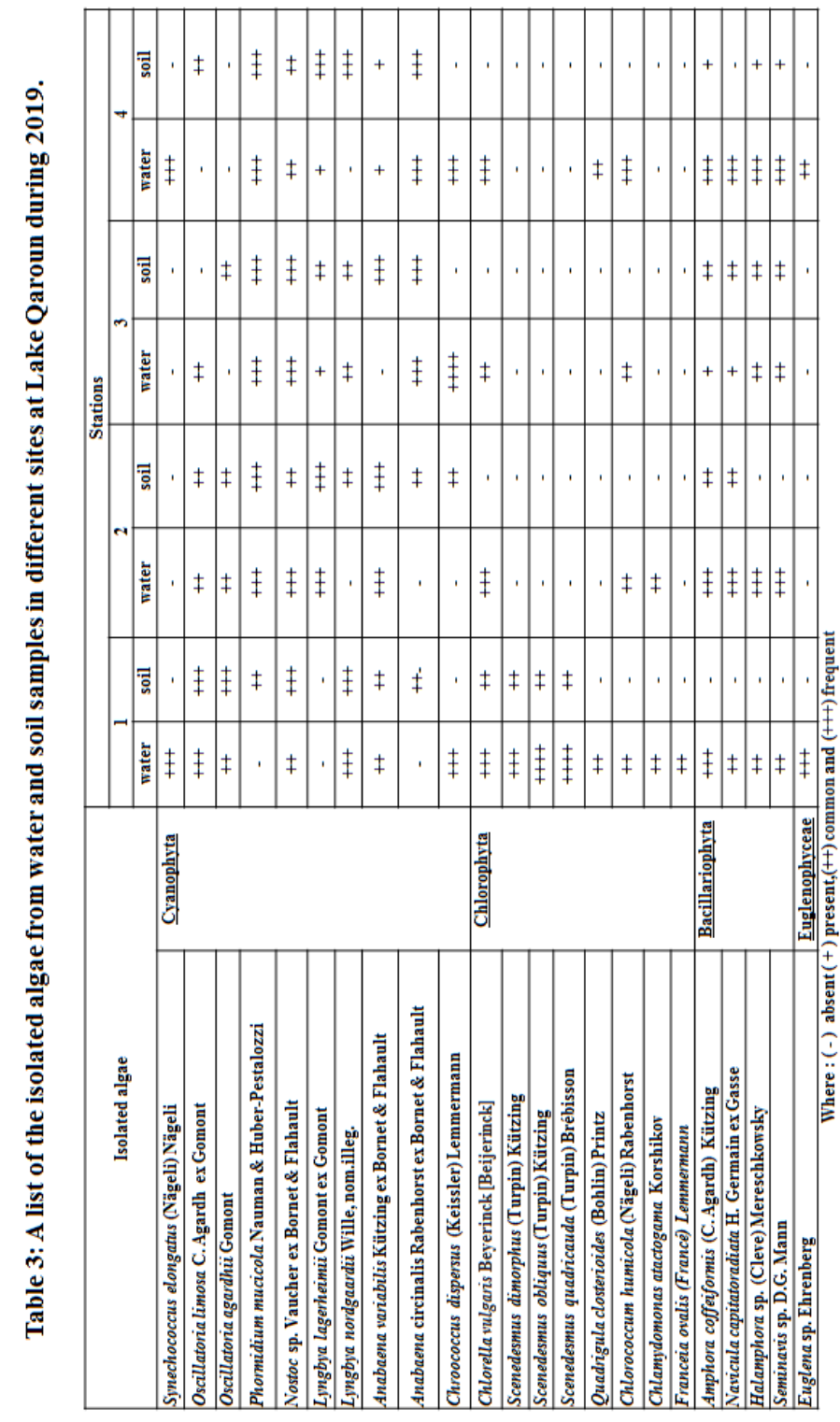


Although, increasing number of phytoplankton (21 different species) of El-Batts drain from other sites we notice a decrease-in percentage of salts and minerals. This may be due to role of Scenedesmaceae biomass for bioremediation processes of heavy metal-contaminated wastewaters, owing to its ability to remove such contaminants, either by adsorption onto the cell surface or by incorporation into the cells themselves. Segura et al. (2016) concluded that Scenedesmus sp. used the waste effluent as a growth substrate, improving its effect during a phycoremediation process. So selection of Scenedesmus quadricauda for cultivation on wastewater to obtain biodiesel was performed.

\section{Total Lipid Content of Scenedesmus quadricauda}

Total lipid content of S. quadricauda was shown in Table 4. The results revealed that the highest total lipid content was detected in S. quadricauda in waste water compared with control $30.6 \%$ and $17.2 \%$ respectively at 18 days. These results agree with Mohaparta (2006) who found that the total lipid of Scenedesmus quadricauda was $19.9 \%$ at normal condition and Shao et al. (2017) showed that the total lipid content of $S$. obliquus was $20.54 \%$ before stress culture then increased to $30.77 \%$ at the ninth day of stress condition.

Table 4: Total Lipid Content (\%) of Scenedesmus quadricauda.

\begin{tabular}{|c|c|c|}
\hline Days & Control & Wastewater \\
\hline 3 & 10.8 & 10.4 \\
\hline 6 & 12.8 & 12.6 \\
\hline 9 & 15 & 22 \\
\hline 12 & 15.2 & 24.8 \\
\hline 15 & 16.6 & 23.8 \\
\hline 18 & 17.2 & 30.6 \\
\hline 21 & 17.2 & 30.4 \\
\hline
\end{tabular}


The content of organic compounds in agro-industrial wastewater, availability of nutrients and cultivation conditions influence the composition of the biomass of the microalgae cultivated in this type of substrate as reported by Kumar and Singh (2019) and Choudhary et al. (2020). In this research, cultivation in the wastewater influenced the metabolism of $S$. quadricauda, directing the flow of carbon fixed by photosynthesis to the synthesis of lipids in higher concentration (30.6\% lipids) compared to the cultures maintained with the standard culture medium (17.2\%) which went parallel with results of Mercado et al. (2020).

\section{Fatty Acids composition of Scenedesmus quadricauda cultivated on wastewater.}

Saturated and unsaturated fatty acids of $S$. quadricauda chloroform / methanol (2:1) extract determined by GC/MS was illustrated in Figures (2 and 3) and Table (5). The major unsaturated fatty acids present in lipids of $S$. quadricauda are, diphenylmethylsilyloxy-2-methyl $25.04 \%$, linolenic acid (polyunsaturated) $1.38 \%$. On the other hand the most important saturated fatty acids present with high concentration was palmitic acid $13.30 \%$ followed by myristic acid $4.68 \%$ and stearic acid which recorded $2.04 \%$ and 12- Methyl-E, E2,13-octadecadien-1-ol with 2.04\%. Moreover, other hydrocarbon compounds (dodecane and tetradecane, 2,6,10-trimethyl) with $2.69 \%$ and $2.32 \%$ respectively.

The content and composition of fatty acids in microalgae are influenced by culture conditions, directly affecting the concentration of FAMEs. In our study, the composition of fatty acids of $S$. quadricauda grown in wastewater showed the dominance of unsaturated fatty acids and less concentration of saturated fatty acids. These results come in harmony with those reported by Mercado et al. (2020). The different composition of fatty acids of $S$. quadricauda, as they may have a significant effect on the characteristics of biodiesel produced. 


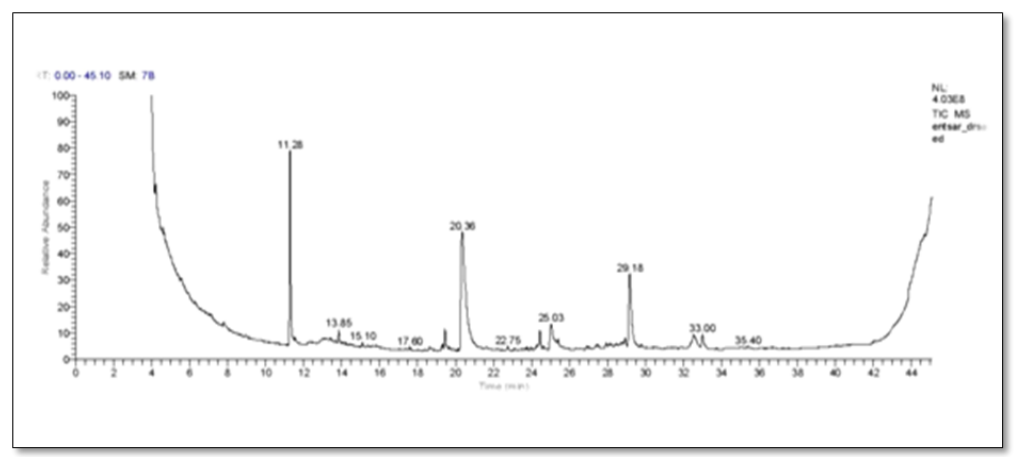

Figure 2: GC - MS of lipid profile from chloroform / methanol (2:1) extract of Scenedesmus quadricauda.

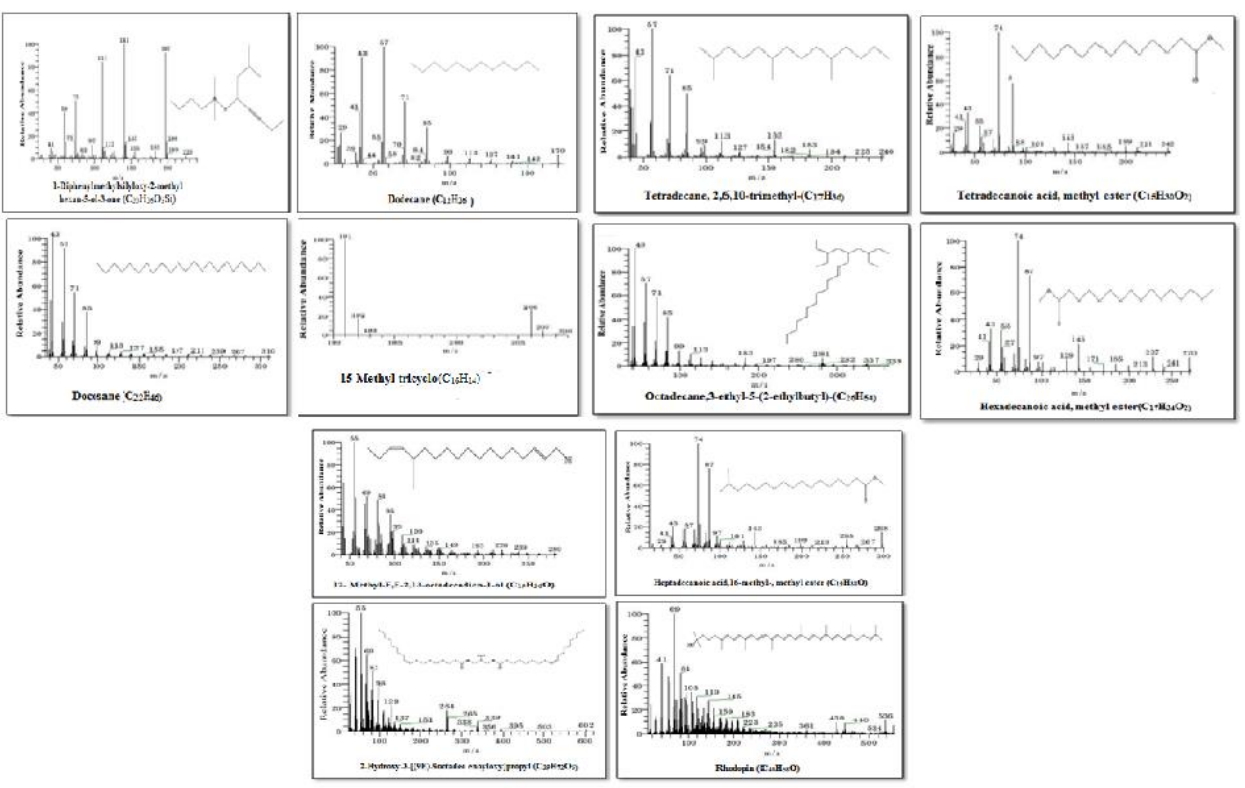

Figure 3: GC - MS for fatty acids compounds with chloroform / methanol (2:1) extract of Scenedesmus quadricauda 
Table (5). GC-MS Analysis of chloroform / methanol (2:1) extract of Scenedesmus quadricauda.

\begin{tabular}{|c|c|c|c|c|c|c|}
\hline No. & RT & Compound & $\begin{array}{l}\text { Compound } \\
\text { Nature } \\
\end{array}$ & $\begin{array}{c}\text { Area } \\
\%\end{array}$ & $\begin{array}{c}\text { Molecular } \\
\text { Formula }\end{array}$ & $\begin{array}{c}\text { Molecular } \\
\text { Weight }\end{array}$ \\
\hline 1 & 11.28 & $\begin{array}{l}\text { Diphenylmethylsilyloxy- } \\
\text { 2-methyl hexan-5-ol-3- } \\
\text { one }\end{array}$ & $\begin{array}{l}\text { Unsaturated } \\
\text { fatty acid } \\
\text { methyl ester }\end{array}$ & 25.04 & $\mathrm{C}_{20} \mathrm{H}_{26} \mathrm{O}_{3} \mathrm{Si}$ & 342 \\
\hline 2 & 13.85 & Dodecane & $\begin{array}{l}\text { hydrocarbon } \\
\text { oily liquid }\end{array}$ & 1.67 & $\mathrm{C}_{12} \mathrm{H}_{26}$ & 170 \\
\hline 3 & 19.44 & Docosane & fatty acid & 2.69 & $\mathrm{C}_{22} \mathrm{H}_{46}$ & 310 \\
\hline 4 & 20.33 & $\begin{array}{c}\text { 15-Methyl tricycle }[6.5 .2 \\
(13,14) .0(7,15)] \\
\text { pentadeca }-1,3,5,7,9,1 \\
\text { T,13-heptene }\end{array}$ & $\begin{array}{l}\text { Unknown } \\
\text { compound }\end{array}$ & 25.58 & $\mathrm{C}_{16} \mathrm{H}_{14}$ & 206 \\
\hline 5 & 24.44 & $\begin{array}{l}\text { Tetradecane, } 2,6,10- \\
\text { trimethyl- }\end{array}$ & hydrocarbon & 2.32 & $\mathrm{C}_{17} \mathrm{H}_{36}$ & 240 \\
\hline 6 & 25.02 & $\begin{array}{l}\text { Tetradecanoic acid, } \\
\text { methyl ester }\end{array}$ & Myristic acid & 4.68 & $\mathrm{C}_{15} \mathrm{H}_{30} \mathrm{O}_{2}$ & 242 \\
\hline 7 & 28.92 & $\begin{array}{l}\text { Octadecane,3-ethyl-5- } \\
\text { (2-ethylbutyl)- }\end{array}$ & $\begin{array}{l}\text { Linolenic } \\
\text { acid }\end{array}$ & 1.38 & $\mathrm{C}_{26} \mathrm{H}_{54}$ & 366 \\
\hline 8 & 29.17 & $\begin{array}{l}\text { Hexadecanoic acid, } \\
\text { methyl ester }\end{array}$ & Palmitic acid & 13.30 & $\mathrm{C}_{17} \mathrm{H}_{34} \mathrm{O}_{2}$ & 270 \\
\hline 9 & 32.54 & $\begin{array}{l}\text { 12- Methyl-E,E-2,13- } \\
\text { octadecadien-1-ol }\end{array}$ & $\begin{array}{l}\text { Unsaturated } \\
\text { fatty acid } \\
\text { methyl ester }\end{array}$ & 2.04 & $\mathrm{C}_{19} \mathrm{H}_{36} \mathrm{O}$ & 280 \\
\hline 10 & 33.00 & $\begin{array}{l}\text { Heptadecanoic acid,16- } \\
\text { methyl-, methyl ester }\end{array}$ & Stearic acid & 2.04 & $\mathrm{C}_{19} \mathrm{H}_{38} \mathrm{O}_{2}$ & 298 \\
\hline 11 & 43.88 & Rhodopin & $\begin{array}{l}\text { Unknown } \\
\text { compound }\end{array}$ & 1.10 & $\mathrm{C}_{40} \mathrm{H}_{58} \mathrm{O}$ & 554 \\
\hline 12 & 44.51 & $\begin{array}{c}\text { 2-Hydroxy-3-[(9E)- } \\
\text { 9octadec } \\
\text { enoyloxy]propyl } \\
\end{array}$ & $\begin{array}{l}\text { Unknown } \\
\text { compound }\end{array}$ & 1.74 & $\mathrm{C}_{39} \mathrm{H}_{72} \mathrm{O}_{5}$ & 620 \\
\hline
\end{tabular}


Mandal and Mallick (2012) evaluated the S. obliquus cultivated in Trenkenshu medium can be used for biofuel because of the quite high content of palmitic acid obtained in this medium is desirable for good quality biodiesel. SFAs may play a double role: as a store of saturated fatty acids to be used as a source of energy and as a store of PUFAs required for phospholipid synthesis to various membrane structures or to be integrated in several metabolic processes.

Results of detailed TEM examinations of $S$. quadricauda, was illustrated in Plate 1-2 which showed the effects of wastewater (as well as the control) on cell ultrastructure of Scenedesmus quadricauda. Plate 1 (A-C) clear $S$. quadricauda normal structure which was characterized at control condition by colony composed of 2-4-8 cylindrical-ovate cells arranged in a single series, outer cells with a long spine at each pole and inner cells with spineless walls and a parietal chloroplast (plate1-A).

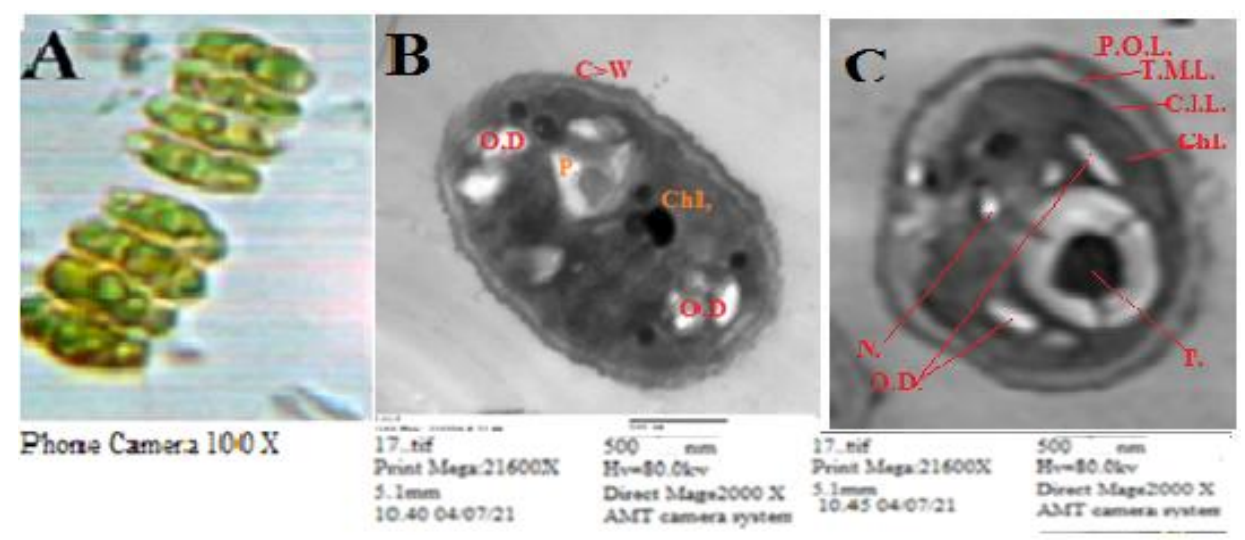

Plate 1: (A) Light microscope view at $100 \times$ showing $S$. quadricauda coenobium (control); (B \& C) Ultrastructure of Scenedesmus at control cell (photo at $500 \mathrm{~nm} \mathrm{X)}$ Where: $\mathbf{C W}=$ Cell Wall; $\mathbf{P}=$ Pyrenoid Chl = Chloroplast; $\mathbf{N}=$ Nucleus $\mathbf{P o l}=$ pectic outer layer; ThML = thin middle layer; $\mathrm{CIL}=$ cellulosic inner layer and $\mathrm{OD}=\mathrm{Oil}$ Droplet 
The ultrastructure of $S$. quadricauda cultivated in wastewater was recorded in plate 2 (A-F). The rigged wall clearly appeared and the number of oil droplet increased largely Plate $\mathbf{2}$ (A-F). Surface modification of cell showed in (Plate 2-B) was associated with lot of irregular surface of cell (plate 2-C).

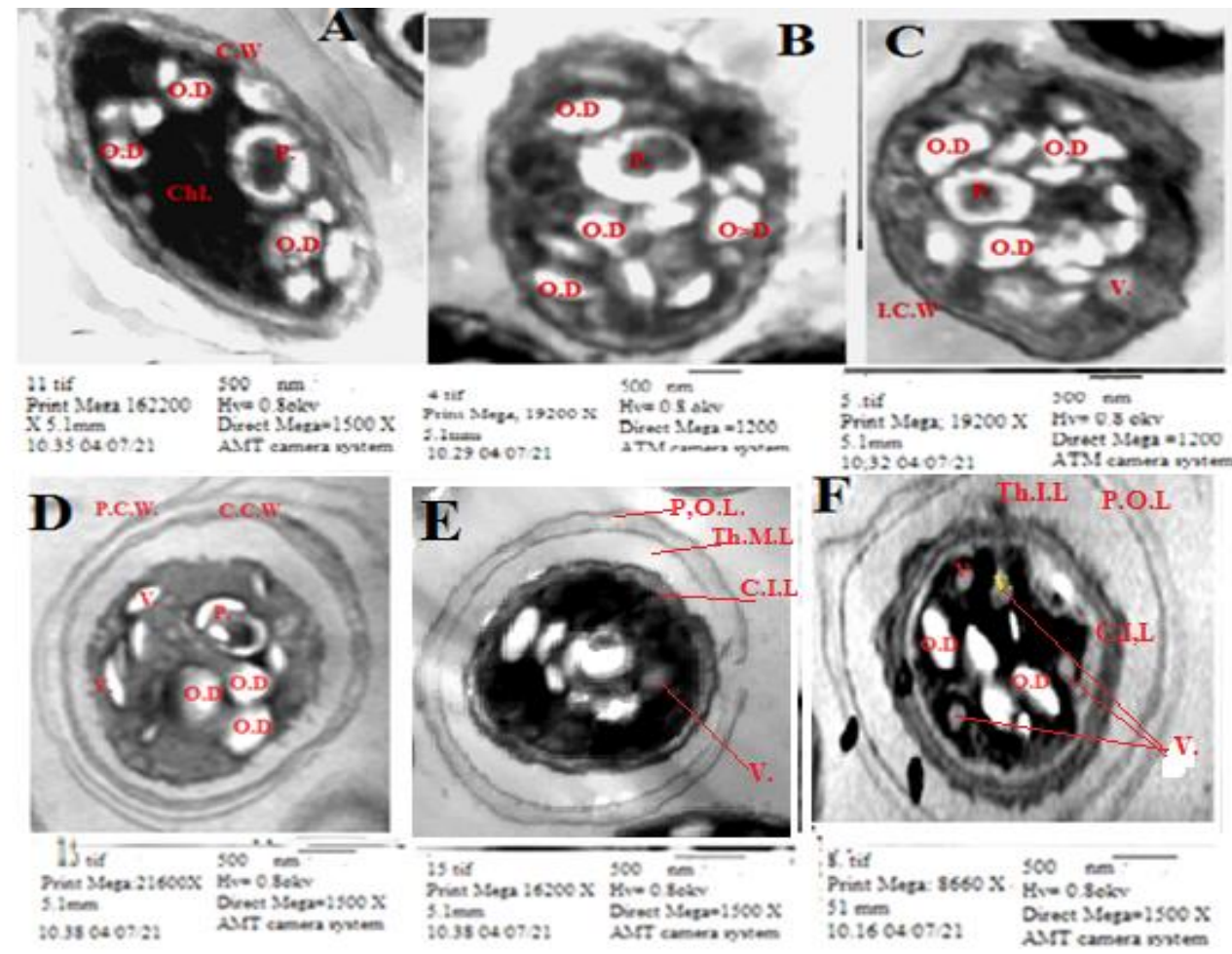

Plate 2: Ultrastructure of $S$. quadricauda cultivated on wastewater Where: $\mathrm{CW}=$ Cell Wall; Pol= pectic outer layer; $\mathrm{ThML}=$ thin middle layer; $\mathrm{CIL}=$ cellulosic inner layer $\mathbf{P}=$ Pyrenoid; $\mathbf{C h l}=$ Chloroplast; $\mathbf{O D}=$ Oil droplet; $\mathbf{I C W}=$ Irregular Cell Wall and $\mathrm{V}=$ Vacuole 
The ultrastructure organization showed that the shrinking and malformations of the cells as well as rounded the cell contents (Plate2-D and E)

Finally, Spherical electron dense bodies were noticed within the cells, pyrenoid disappeared, number of vacuoles increased and that the carbohydrates diffused out of the cell interiors and its accumulation on the surfaces. These led to change in the morphology of cells (Plate2-F). Accumulation of starch results in the disarrangement of the chloroplasts, as reported by (Wong et al., 1994 and Miao and Wang, 2006) who agreed with our results.

Gushina and Harwood (2009) recorded the cytoplasmic oil droplets are accumulated under stressful environmental conditions, such as high temperature, light intensity and rise in salinity.

Said and Shehab (2018) conclude that the starch granule increases in size of $S$. quadricauda under stress due to the rapid mitochondria deterioration caused accumulation of starch grains which may act as energy reserve to the cell after the deterioration of organelles especially mitochondria, chloroplast, and pyrenoid.

Also, chloroplast was deformed, detachment of the cell membrane from the cell wall was frequently observed in stressed cells, it may be due to the degradation products of cellular constituents, (extracellular substances produced under stress) which filled the cellulosic layer (Maršalek and Rojıcková, 1996; Mishra and Jha, 2009). Spherical electron dense bodies were noticed within the cells and the number of vacuoles increased due to heavy metal and salinity stress this is related to vacuolation could contribute to compartmentalization of toxic metals (Crang and Jensen 1975). Kahoko et al. (2003) recorded that electron dense deposits were from polyphosphate bodieswhich have the ability to protect algal cells from metal toxicity and also to accumulate metals (as chelated phosphate-metal bodies).

The cell wall of Scenedesmus sp. consists of 3 layers: the inner cellulosic layer which delimits individual cells; the outer pectic layer which binds the cells of the coenobium together; and a thin middle layer, bounded by membranes on either side Blsalputra and Weier (1963). Plate (2-F) also clearly demonstrated the effect of wastewater on S. quadricauda which indicated changes in the cell wall structure especially of inner layer of cell wall (cellulose layer). It 
showed thickness all over the cell wall surfaces. These results showed an agreement with Soo Ha et al. (2020) who observed that changes in the cell wall structure and thickness before and after fermentation using transmission electron microscopy of three different microalgal strains. Thickness of wall was due to increase of PUFAs (polyunsaturated fatty acids) required for phospholipid synthesis of cell wall membrane structures. Vance and Vance (2002) suggested the Polar lipids are structural components of cell membranes, where they participate in the formation of the permeability barrier of cells and subcellular organelles in the form of a lipid bilayer. The major lipid type defining this bilayer in almost all membranes is glycerol-based phospholipid. The importance of the membrane lipid physical (phase) state is evidenced by the fact that lipids may control the physiological state of a membrane organelle by modifying its biophysical aspects, such as the polarity and permeability. Rashidi and Trindade (2018) recorded the carbohydrate content in the cell wall of $N$. oleoabundans accounts for $24.3 \%$ of the total cell wall biomass. However, our results support the effect of wastewater on cell wall structure and morphology of cells which was altered by their tendency to accumulate lipids and carbohydrates in organelles of cell.

\section{Conclusion}

From the above result it has been concluded that the Qaroun Lake showed high dominance of microalgae which indicated that this lake posse's high amount of organic wastes and therefore the water of the Lake is organically polluted. Taking into account that it is possible to take advantage of the wastewater pollution of the lake as phytoremediation and work to purify it of its pollutants by using different types of algae, as S. quadricauda to produce biodiesel from wastewater which is good substrate for biodiesel production after the biological removal of contaminants. 


\section{References}

Abdel Hameed, M. S.; Hammouda, O.; Kobbia, I. and Hassan, S. (2007). Correlation between algal taxa and physico-chemical characters of the protected area of Wadi El-Rayan, Egypt. Int. J. Agri. Biol., 9(1): 1-10.

Abdel-Moniem, A. (1991). Changes in phytoplankton composition of Lake Qaroun in relation to variation in salinity. M. Sc. Thesis, College of Girls, Ain Shams University, Egypt

Abdel-Moniem, A. and Konswa, A. (2001). Some biotic and abiotic variables controlling primary productivity in hypertrophic lake (Lake QarounEgypt).

Abdel-Satar, A. M.; Elewa, A. A.; Mekki, A. K. T. and Gohar M. E. (2003). Some Aspects on Trace Elements and Major Cations of Lake Qaroun Sediment Egypt. Bull Fac. Sci. Zagazig Univ. Egypt, 25:77 - 97.

Abdel-Satar, A.M. and Sayed, M.F. (2010). Sequential fractionation of phosphorus in sediments of El-Fayum lakes-Egypt, Environ Monit. Assess., 169: 169-178.

Abdel Wahed, M. S. M.; Mohamed, E. A.; Wolkersdorfer, C.; El-Sayed, MI.; M'nif, A. and Sillanpaa, M. (2015) . Assessment of water quality in surface waters of the Fayoum watershed, Egypt. Environ. Earth. Sci., 74: 1765 - 1783.

Al-Afify, A. D. G.; Tahoun, U. M. and Abdo, M. H. (2019). Water Quality Index and Microbial Assessment of Lake Qaroun, El-Batts and El-Wadi Drains, Fayoum Province, Egypt. Egyptian J. of Aq. Biology \& Fisheries Zoology Department, Faculty of Science, Ain Shams University, Cairo, Egypt. ISSN 1110 - 6131 Vol. 23(1): 341 -357

Asmus, H. (1982). Field measurements on respiration and secondary production of a benthic communitv in the northern Wadden Sea. Netherlands I. of Sea. Res., 1(6): 403-Y 413. 
Authman, M.M.N. and Abbas, H.H.H. (2007). Accumulation and distribution of copper and zinc in both water and some vital tissues of two fish species (Tilapia zillii and Mugil cephalus) of Lake Qaroun, Fayoum Province, Egypt. Pakistan Journal of Biological Sciences, 10(13): 2106-2122.

Ball, J. (1939). Geography of Egypt. Buluq Press, Cairo, 221pp.

Blsalputra, T. and Weier, W. e. (1963). The cell wall of Scenedesmus quadricauda .American Journal of Botany, 11 Vol. 50; Iss. 10

Browitzka, M.A. and Browitzka, L.J. (1988). Microalga. And Biotechnology. Cambridge University Press, Cambridge, pp: 456-458.

Choudhary, P.; Assemany, P.P.; Naaz, F.; Bhattacharya, A.; Castro, J.D.S.; Couto, E.D.A.D.C.; Calijuri, M.L.; Pant, K.K.; Malik, A. A. (2020). review of biochemical and thermochemical energy conversion routes of wastewater grown algal biomass. Sci. Total. Environ., 726, 137961.

Crang, R.E. and Jensen, T.E. (1975). Incorporation of titanium in polyphosphate bodies of anacystisnidulans. J. Cell Biol., 67:80.

El-Awamri, A. A. (1984). Diatoms of El-Fayum province. Ph.D. Thesis. Fac. of Sci. Ain Shams Univ., 175 pp.

Fathi, A.A. and Flower, J.R. (2005). Water quality and phytoplankton communities in Lake Qaroun (Egypt). Aquat. Sci. 67: 350-362

Ferrigo, D.; Galla, G.; Sforza, E.; Morosinotto, T.; Barcaccia, G. and Berrini, C.C. (2015). Biochemical characterization and genetic identity of an oilrich Acutodesmus obliquus isolate. J Appl. Phycol.; 27(1): 149-161

Folch, J.; Lees M. and Stanley, G.H.S. (1957). A simple method for the isolation and purification of total lipides from animal tissues. $\mathrm{J}$ Biol Chem. 226(1):497-50

Gani, P.; Mohamed, N.; Matias-peralta, H. and Latiff, A.A.A. (2016). Application of Phycoremediation Technology in the Treatment of Food Processing Wastewater by Freshwater Microalgae Botryococcus sp., $J$. Eng. Appl. Sci., 11, 7288-7292 
Goswami, R. and Kalita M.K. (2011). Scenedesmus dimorphus and Scenedesmus quadricauda: Two potent indigenous microalgae strains for biomass production and $\mathrm{CO}$ mitigation a study on their growth behavior and lipid productivity under different concentration of urea as nitrogen source. J Algal Biomass Utilization. 2(4): 42-49.

Gushina I.A. and Harwood J.L. (2009). Algal lipids and effect on the environment on their biochemistry. In: Arts MT, Brett MT, Kainz M, editors. Lipids in Aquatic Ecosystems. Springer-Verlag New York; p. 124. doi:10.1007/978-0-387-89366-2_1.

Hutchison, G.E. (1957). A treatise on Limnology Vol.1. Geography, Physics and Chemistry. John Wiley and Sons Inc. New York. 1011pp

Jackson, M.L. (1962). Soil Chemical Analysis, P: 498. London, Constable and Co. Ltd

John, R.P. (1942). An ecological and taxonomic study of the algae of the British soils. The distribution of the surface growing algae. Ann. Bot., 6: 3 23-49

Kahoko, N.; Yoko. Y.; Isao, U. and Noriko, T. (2003). Ultrastructure changes in Chlamydomonas acidophila (Chlorophyta) induced by heavy metals and polyphosphate metabolism. FEMS Microbiol. Ecol., 44: 253 - 259.

Kobbia, I.; Zaki, M. and Gad, Y. (1992). Ecology of phytoplankton in estuarine regions of Abua Tarfaia drain in Lake Quarun (Egypt). Mansoura Sci Bull Egypt, 19: 141-165.

Kobbia, I.A., (1982). The standing crop and primary production of phytoplankton in lake Brollus. Egypt J. Bot., 25: 109-28.

Kumar, D. and Singh, B. (2019). Ankit. Phycoremediation of nutrients and valorisation of microalgal biomass: An economic perspective. In Application of Microalgae in Wastewater Treatment, 1st ed.; Gupta, S., Bux, F., Eds.; Springer: Cham, Switzerland; Volume 2, pp. 1-15

Lashari, K. H.; Korai A. L.; Sahato G. A. and Kazi T. G. (2009). Limnological Studies of Keenjhar Lake, District, Thatta, Sindh, Pakistan. Pak.J. Anal. Environ. Chem. 10(1-2): 39-47 
Lürling, M. ; De Lange, H.J. and Van Donk, E. (1997). Changes in food quality of the green alga Scenedesmus induced by Daphnia infochemicals: biochemical composition and morphology. Freshwater Biol. 1997; 38: 619-628. doi: 10.1046/j.13652427.1997.00225.x.

Mandal, S. and Mallick, N. (2012). Biodiesel production by the green microalga Scenedesmus obliquus in a Recirculatory Aquaculture System. Appl. Environ. Microbiol., 78(16): 5929-5934.

Maršalek, B. and Rojıcková, R. (1996). Stress factors enhancing production of algal exudates: a potential self-protective mechanism? Z. Naturforsch., 51:646-650.

Mercado, I.; Álvarez, X.; Eloiza, M. V. and Cruz, A. (2020). Enhancement of Biomass and Lipid Productivities of Scenedesmus sp. Cultivated in the Wastewater of the Dairy Industry. November 2020.

Meshal, A.N. (1977). The problem of the salinity increase in Lake Qaroun (Egypt) and aproposed solution J. Cons. Ins. Explor. Mer., Vol. 37 (2): 137-143.

Miao, A.J. and Wang, W.X. (2006). Cadmium toxicity to two marine phytoplankton under different nutrient conditions. Aquat.Toxicl., 78: 11426.

Mishra, A. and Jha, B. (2009). Isolation and characterization of extracellular polymeric substances from micro-algae Dunaliella salina under salt stress. Bioresource Technol., 100: 3382-3386.

Mohapatra, P.K. (2006). Biotechnological approaches to microalga culture. In: Textbook of environmental biotechnology. IK International Publishing House Pvt. Ltd, New Delhi, India, pp. 167-200

Nair S. K. ; Shehana R. S. ; Girija V. K. \& Meenakumari K. S. (1993). Sensitivity of blue green algae to soil reaction- a factor affecting its efficient use as biofertilizer. Journal of Tropical Agriculture., 31(1): 116 118.

Palade, G. E; Zagury, D; Uhr, J .W. and Jamieson, J. D. (1952). Histoautoradiography study of immunoglobulin biosynthesis of mouse 
myeloma plasmacytes. Comptes Rendus Hebdomadaires des Séances de l'Académie des Sciences. Série D: Sciences naturelles, 268:1664-1667.

Prescott, G.W. (1962). Algae of the Western Great Lakes Area, P: 517. Brown, W.M.C. Com. USA.

Rashidi, B. and .Trindade, M.L. (2018). Detailed biochemical and morphologic characteristics of the green microalga Neochloris oleoabundans cell wall. Algal Research, 35: 152-159

Rasmy, M. and Estefan, S.F. (1983). Geochemistries of saline minerals separated from Lake Qaroun reject water. Chem.Geol.40, 269-277

Reid, G.K. (1961). Ecology of Inland Water and Estuaries. Reinhold Publishing Corporation. NewYork. 375 pp

Round, F.E. (1984). The ecology of Algae. Cambridge University Press, Cambridge, pp: 79.

Said, H.A. and Shehab, R. A. (2018). The Effects of Sewage Water on Ultrastructure of Chlorella vulgaris and Scenedesmus quadricauda Egyptian J. of Phycol., 19: 23-46.

Segura, M. B.; Luisa, H. R.; David, P. O. ; Asly Veg, B. and Karen, P. (2016). Using Scenedesmus sp. for the Phycoremediation of Tannery Wastewater Uso de Scenedesmus sp. para la Ficorremediación de Aguas Residuales de Curtiembres DOI:http://dx.doi.org/ 10.18180/ tecciencia.21.11

Shao, Y. ; Fang, H. ; Zhou, H. ; Wang, Q. ; Zhu, Y. and Yong He (2017). Detection and imaging of lipids of Scenedesmus obliquus based on confocal Raman microspectroscopy Biotechnology for Biofuels volume 10, Article number: 300 .

Singh, R.P.R. ; Bongale U.D. and Rajaro V.N. (1990). Algal flora of paddy fields from Sirsi,Karnataka State. Proceeding of the International Symposium on Phycology, Madras, India., 431-434.

Singh, D.V; Bhat, R.A; Upadhyay, A.K.; and Singh, DP. (2021): Microalgae in aquatic environs: A sustainable approach for remediation of heavy metals and emerging contaminantsn. Environmental Technology \& Innovation, 21. 101340 
Soo Ha, G. ; El-Dalatony, M.M. ; Kim, H.D ; Salama, E. ; Kurade, B. ; Roh, H.S. ; Abomohra, A. and Hun, B.J. (2020). Biocomponent-based microalgal transformations into biofuels during the pretreatment and fermentation process. J. Biortech.; 302:122809.

Staub, R. (1961). Ernähr unzsphysiologish autökologische untersuchengen an der planktischen blau-alg Oscillatoria rubescence. D.C. Scheweiz. Zeitschr Hydrobiologie, 23: 82-198.

Vance, E. and Vance, J .E (2002). Biochemistry: Biochemistry of Lipids, Lipoproteins and Membranes, 4th edition, 2002.

Vogel, A.I. (1961). A Textbook of Quantitative Inorganic Analysis, ( $3^{\text {rd }}$ Ed.), P: 583. Longmans, Green, London.

Wong, S.L.; Nakamoto, J.F. and Wainwright, J.F. (1994). Identification of toxic metals in affected algal cells in assays of wastewaters. J. of Applied Phycol.,6: 405-414.

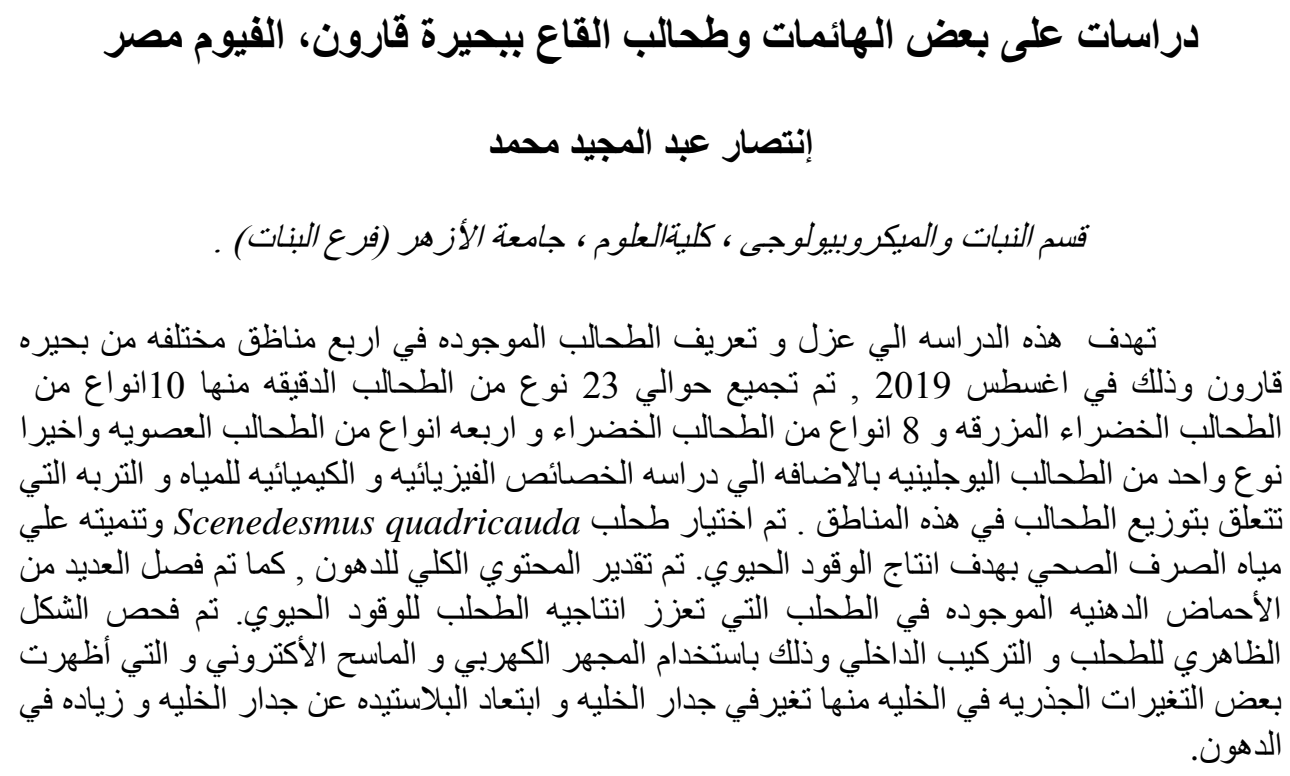

